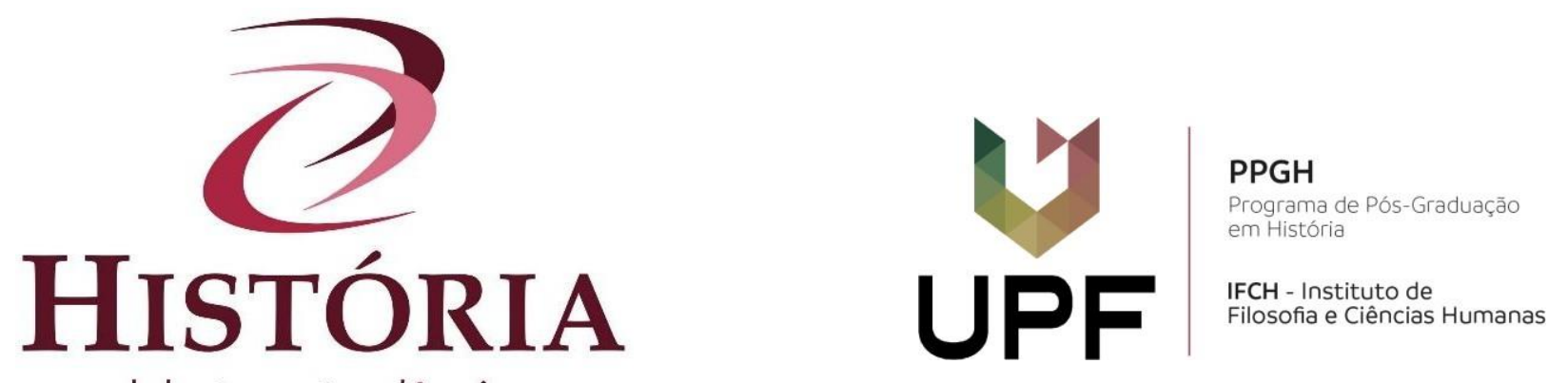

debates e tendências

\title{
Sports journalism, culture and politics in Brazil: \\ An analysis of the role of the press in the formation of Rio de Janeiro's football supporters groups during the 1960s
}

\author{
Jornalismo esportivo, cultura e política no Brasil: Uma análise do
}

papel da imprensa na formação dos grupos de torcedores do futebol do

Rio de Janeiro nos anos 1960

Periodismo deportivo, cultura y política en Brasil: un análisis del papel

de la prensa en la formación de los grupos de aficionados al fútbol de

Rio de Janeiro en la década de 1960

Bernardo Borges Buarque de Hollanda ${ }^{\mathrm{i}}$

\begin{abstract}
The year of 1968 was also marked by unrest and riots in the stands of Maracanã stadium. In a period of poor performance of their teams, groups of young football fans threw themselves into the fight against directors of big clubs in Rio, through protests, demonstrations and even marches outside Rio de Janeiro's stadium. Inspired by the international slogan Youth Power, these newly formed groups adopted similarly a critical stand on the traditional model of supporters, the "Charangas" (small music bands), originated in the 1940s, characterized by the prevalence of a single charismatic leader, recognized by the Club and by the majority of its fans. During the 1970s, the dissident Young Supporters Groups are established on the sports scene and make possible the emergence of a multitude of small and medium-sized associations, giving the supporting activity associative and cultural meanings, recreational and social, until then non-existent in a period of civil-military dictatorship (1964-1985). By gathering these events derived from the serial reading of journalistic narratives, obtained in sports newspapers archives, this article aims to show how a particular type of association, based on club idolatry, took shape on a national and international scale in the 1960s, 1970s and 1980s, and assumed historical and cultural particularities in professional football in Rio de Janeiro. We sought to demonstrate how this phenomenon from the second half of the $20^{\text {th }}$ century met the new demands for participation and differentiation of urban populations, especially its young protagonists, in an increasingly competitive, massified and commodified professional field.
\end{abstract}


Keywords: Brazilian football. Young football fans. Politics and culture in the 1960s.

Resumo: O ano de 1968 também foi marcado por distúrbios e tumultos nas arquibancadas do estádio do Maracanã. Em um período de fraco desempenho de suas equipes, grupos de jovens torcedores jogaram-se na luta contra diretores de grandes clubes do Rio, através de protestos, manifestações e até marchas fora do estádio do Rio de Janeiro. Inspirados pelo slogan internacional Youth Power, esses grupos recém-formados adotaram similarmente uma posição crítica sobre o modelo tradicional de apoiadores, as "Charangas", originadas na década de 1940, caracterizadas pela prevalêcia de um único líder carismático, reconhecido pelo Clube e pela maioria dos seus fãs. Durante a década de 1970, os Grupos de Jovens Defensores dissidentes são estabelecidos no cenário esportivo e possibilitam o surgimento de uma infinidade de associações de pequeno e médio porte, dando à atividade de apoio significados associativos e culturais, recreativos e sociais, até então inexistentes em um período de ditadura civil-militar (1964-1985). Ao reunir esses eventos derivados da leitura em série de narrativas jornalísticas, obtidos em arquivos de jornais esportivos, este artigo tem como objetivo mostrar como um tipo particular de associação, baseado na idolatria de clubes, tomou forma em escala nacional e internacional nos anos 1960, 1970 e 1980, e assumiu particularidades históricas e culturais no futebol profissional no Rio de Janeiro. Buscamos demonstrar como esse fenômeno da segunda metade do século XX atendeu às novas demandas de participação e diferenciação das populações urbanas, especialmente dos jovens protagonistas, em um campo profissional cada vez mais competitivo, massificado e mercantilizado.

Palavras-chave: Futebol brasileiro. Jovens fãs de futebol. Política e cultura na década de 1960.

Resumen: El año 1968 también estuvo marcado por disturbios y disturbios en las gradas del estadio Maracanã. En un período de bajo rendimiento de sus equipos, grupos de jóvenes simpatizantes se lanzaron a la lucha contra los directores de los principales clubes de Río a través de protestas, manifestaciones e incluso marchas fuera del estadio de Río de Janeiro. Inspirados por el eslogan internacional "Poder Juvenil", estos grupos recién formados adoptaron de manera similar una postura crítica con respecto al modelo tradicional de partidarios, los "Charangas", originados en la década de 1940, caracterizados por la prevalencia de un único líder carismático reconocido por el Club y la mayoría. de tus fans. Durante la década de 1970, los Grupos de Jóvenes Defensores Disidentes se establecieron en el panorama deportivo y permiten el surgimiento de una multitud de asociaciones pequeñas y medianas, lo que da a la actividad de apoyo significados significativos, culturales, recreativos y sociales que antes no existían. Un período de dictadura civil-militar (1964-1985). Reuniendo estos eventos derivados de la lectura en serie de narrativas periodísticas de archivos de revistas deportivas, este artículo pretende mostrar cómo un tipo particular de asociación, basada en la idolatría de clubes, tomó forma a escala nacional e internacional en la década de 1960. 1970 y 1980, y asumió particularidades históricas y culturales en el fútbol profesional en Río de Janeiro. Buscamos demostrar cómo este fenómeno de la segunda mitad del siglo XX cumplió con las nuevas demandas de participación y diferenciación de las poblaciones urbanas, especialmente los jóvenes protagonistas, en un campo profesional cada vez más competitivo, masificado y comercializado.

Palabras clave: Fútbol brasileño. Los jóvenes fanáticos del fútbol. Política y cultura en los años sesenta. 


\section{Introduction: preliminary theoretical considerations}

The general aim of this article is to gather the parameters of an object that may be considered unusual for historiography. If football's relevance as a historical investigation topic is still today questioned, as happened once with phenomena considered trivial, such as the climate, the body and the kitchen, what can be said of an epiphenomenon of football activity and professionalism in sports, i.e., supporters groups, within the scenario more conventional discussions of historiography?

In this sense, the choice here made is linked to a debate held by French historians during the 1970s concerning the emergence of new objects of study in historiography. In 1974, Jacques Le Goff and Pierre Nora published the three-volume work Faire de l'Histoire, in which a heterogeneous group of historians sought to do, not an examination nor a panorama, but a diagnosis of historical writing in the present, based on three main symptoms identified by them: new problems, new approaches and new objects (NORA; LE GOFF, 1988).

To question history's own identity as a science of the past, dedicated to elaborate explanatory systems that explain society through time, the coordinators of the volume talked about historians become aware of the paths pointed out by contemporary historical research. The examination subsequent to historians' "awareness" concerned the expansion of history epistemological field in contemporaneity.

Such expansion, which followed general changing in modern sciences and that, in turn, implied a threat of blurring its boundaries, consisted of progressive annexation of different domains and incorporation of diverse fields of knowledge, since the exhaustion of totalities, whether of positivist history or of philosophy of history. The New History was, therefore, defined as a science of the present, of change and fragmentation, and it rejected those who were imbued with ideas of an omniscient voice from the past and time selfconsciousness.

If the volume dedicated to new objects does not mention sports - it is known that only in the 1980s Roger Chartier would articulate the theme with Pierre Bourdieu and Norbert Elias ideas - the volumes devoted to new problems had an acute and dense reflection on the historical narrative traced by one of the volume editors.

Its understanding is important here for explaining how "the problem" of this article was developed. Pierre Nora's essay "The return of the event" was originally published in 1972 for the magazine Communications with the suggestive title "L'evénement monstre" and would be expanded in the vast compendium entitled Les lieux des memoires. Under his direction, the opulent work scrutinizes the most important "places of memory" in the 
production of events related to the Republic and the French Revolution, in a catalogue of parties, emblems and monuments; celebrations, dictionaries and museums.

However, within the limits of that essay from the early 1970s, the author addresses an issue at first glance inconceivable to those who had already considered positivism over: the importance reassumed by events in daily, social and political life. It is certain that such resurgence, after the intermezzo of structural history, did not happen in the same way as simple exhumation or rediscovery of a scientific tradition, but under the influx of new production conditions, with a radically different status from that postulated by $19^{\text {th }}$-century positivists.

While the Rankean paradigm aimed at raising the historian to supreme arbitrator of the past, showing facts as it actually happened by means of temporal distance that allows him to capture the coherent order and nexus underlying immense amount of data, the fact now, past three quarters of the $20^{\text {th }}$ century, was produced in close connection with the present, with what was lived and with the instantaneous. The fact relationship with present time became conditioned by its connection with the mass media, i.e., its inextricable association with mechanical-mediatic reproduction of written, sound and visual language.

The extraordinary capacity of the media to create events, in the form of processes, scandals and cases, transform particular incidents in huge historical events. The press, the radio and the television are not only means of delivering news, but its own condition of existence, open way of production and recognition: "The fact that they happened does not make them historical. For an event to happen it must be known".

The loss of authority over the fact, previously enclosed in the official dome of the past, makes the historian bend over the entanglement of the real and the everyday life with its mediatized and spectacularized expression. The reporter, the emerging figure that witnesses and transmits the modern event, that is, the eyewitness of the "wonders of democratic societies", becomes the individual capable of giving a spectacular touch to events, whose most fantastic example for Nora was the live broadcast of the moon landing in the end of the 1960s.

Pierre Nora's thoughts on production, metamorphosis and paradoxes of a "return of the fact" in the last quarter of the $20^{\text {th }}$ century supports this article's general set of problems. The limitation of the study to events reported in Rio de Janeiro by the press in the year of 1968 can only go through the analysis of mediatized production of information, since the approach to the object of study is made through it.

Despite the potential traps and ambushes in football supporters stereotypes and their representation in the media, the path chosen here is to work with press sources, in particular the archive of the Jornal dos Sports, main reference of sports journalism in Rio de Janeiro between the 
1930s and the 1980s.

\section{Limitation of the problem: sports journalism and supporters' protests in the late 1960s}

To make this article, we relied on contextual information on the aforementioned newspaper pointed out by anthropologist José Sérgio Leite Lopes in the essay: "The football victory that incorporated the amateur game: the invention of sports journalism and the admission of black players in Brazilian football" (LOPES, 1994). The analysis of the essay allowed us to approach the topic using the "intrigue" sequence described by the author concerning Mário Filho’s family, the owner of Jornal dos Sports.

The spectrum defined by Leite Lopes consisted of Mário Filho's biography and his ability to socially rehabilitate his family through the appreciation of sports press between the 1930s and the 1960s, in an analysis that goes until his death in 1966. Subsequently, the time frame here adopted, in turn, sought to follow the plot and expanded the narrative to the second half of the 1960s.

By serial reading of the Jornal dos Sports, the succession of Mário Filho's only son to his father's commercial project in the newspapermade possible to follow the invention of a series of new events by Mário Júlio. Although he followed his father editorial tradition, he had to adapt to economic contingencies and imposed historical and political circumstances from the late 1960s.

The Supporters Duel, a competition between supporters of rival clubs, invented by Mário Filho in the 1930s was one of the traditions that Mário Júlio continued on the pink pages of the newspaper, although he had adapted it to new sport audiences forms in the 1960s. Even with a new generation taking charge of the newspaper, aid for supporters groups' activities during the 1960s, 1970s and 1980s would continue as the signature of a newspaper that historically had a close connection with them.

Whether the inter-class character of professional football predicated by Mário Filho also encompassed the intergenerational profile of match goers and sports newspaper readers, the prevalence of youngsters was a reality increasingly noticeable in society and in the football scene in the second half of the $20^{\text {th }}$ century.

Mário Júlio soon would incorporate to the newspaper editorial discourse and commercial strategy the motto of the youth phenomenon, the so-called international "young wave", which then seemed contagious. For this purpose, in the late 1960s, the $J S$ was selfproclaimed "the Youth Power newspaper", insofar as it sought to walk alongside students and youth sector, whether in language or in common goals. 
Such coordination was made through many articles and cultural criticism - music, theatre, movies, science, television, visual arts - that went beyond the traditional sports section, making the newspaper plural and free from restraints for new columnists. Thus emerged in the newspaper's pages the monthly section called $O$ Sol, one of the youth symbols of the 1968 generation, found in the verses of the tropicalist composer Caetano Veloso.

This interactive process with the reader and this broader scope that sports provide to perception, following a ginzburgian trail (GINZBURG, 1990), of a connection between the newspaper message and the appearance of supporters' groups. It is in the late 1960s that the dissident supporters' groups appear in Rio de Janeiro, called Young Supporters Groups, ending the monopoly of the traditional "Charangas". Inspired by the international slogan Youth Power, which had become the motto of Jornal dos Sports, these incipient groups of supporters would be favored by privileged positive coverage given by $J S$ to Young Supporters Groups.

As a result, many groups were created under the sign of protest and non conformity, whether regarding club management and the unsatisfactory performance of the teams, or the leaders of the team's supporters. Such separation seems of extreme importance, a watershed in the identity formation of the supporters' groups, that would multiply in the 1970s, in the form of tens and even hundreds of groups organized in the neighbourhoods. Always with the support of Jornal dos Sports, which would continue to promote contests and awards, these associations would develop dialogue channels that would approximate each other, as well as conflicts and quarrels that would tear them apart.

The strategy used here is to follow the track that raises as a "problem", that is, the close bonding of construction of the news and the construction of the social fact in contemporaneity, in the form of public opinion in general and fan's behavior in particular. The main prerogatives in the approach to the object are taken into account: that it is a specialized newspaper and representative of the fan-readership; it is a newspaper traditionally favorable and open to football supporters, based on interactivity; the paper is not just a communication channel, but a sine qua non condition to recognize an event, as said the aforementioned Pierre Nora.

Against the tyranny of the event, the passivity in the contemporary world would not be the only effect of this domination. From the point of view here supported, the mediatized event founding force, which is perceived in the newspaper narratives, with its approach of supporters' groups, is not the only existing force. Next to the headlines, the news, the 
caricatural drawings and the articles, it is possible to follow, through a little opinion piece of the newspaper, the fans discursive practice and interaction in their daily lives.

The "Bate-Bola" section as a concession of the newspaper to its reader's opinion demonstrates how the exchange and dialogue were possible even in the media dominated by high technology. Thus, more than mere effect of reification, the supporters' groups were agents of a reality in construction not only in the stands, but also in the language, in the communication and in the space granted in a mass media vehicle.

\section{Mário Filho legacy in the Brazilian journalistic, political and cultural context of the 1960s}

In Brazilian sports memory, the second half of 1966 would be remembered by the Brazilian football squad loss at the World Cup held in England. The commotion caused by the squad's defeat and mediocre performance in that tournament, which would delay for another four years Brazil's third championship, would be followed by the painful loss of one of the most active and prominent personalities in Brazilian sports world: Mário Rodrigues Filho. The 58-year-old Brazilian journalist's death represented the end of a life entwined with the history of professional football and with the creation of one of the greatest mass spectacles in the country. During a period of four decades - from the 1920 s to the 1960 s Mário Filho exerted a large influence on sports, culture and politics.

On the occasion of his death, the superlatives assigned to Mário Filho mobilized equally concrete actions to fix a great image and create a "memory place" to the journalist in posterity. The suggestion that Nelson Rodrigues, chronicler and his younger brother, sent to the City Council, resulted inchanging the name of Rio de Janeiro Municipal Stadium, Maracanã, to Mário Filho Stadium, a sports square he made every effort to build in the late 1940s.

In the newspaper case, however, the impact of its creator death brought significant internal changes. His only son, Mário Júlio Rodrigues, was entitled to receive in 1967 the highest position that once belonged to his father in the newspaper. The succession, nevertheless, would not be in the following years a mere authority transfer, as just a maintenance and administration of the patrimonial heritage. As happened with his grandfather and his father, when the latter saw in sports, according to anthropologist José Sérgio Leite Lopes, a new way of doing politics, the third generation of the family tree would also imprint his specific signature in sports journalism in the late 1960s. 
Although always inspired by his father example, a considerable expansion of the current sports journalism concept was noticeable in the successor, following transformations in the graphic and cultural industry initiated in the previous decade. Besides changes in content and information published, the new style followed editorial reforms that were occurring in other Brazilian newspapers of the late 1950s.

Jornal dos Sports would adhere to the new tendencies and change its editorial policy, but not without struggle, having severe financial difficulties, which over time Mário Júlio Rodrigues would cope with. The initial alternative to the newspaper fragile situation was diversification of its audience and expanding the thematic scope of its articles.

If sports news continued to be the newspaper's cornerstone, soon it would have different topics alongside them, which included student and cultural journalism. Even though Mário Filho had already developed with mastery the union of football and popular music since the 1930s, sports would now be integrated into a broader context, covering also topics related to culture, education and youth.

\section{Sports press and the rising of youth as cultural and political actors in the 1960s}

The readers of Jornal dos Sports limited before to an audience that just wanted to keep up daily with football, would acquire a new profile, or else, would have to get used to a variety of events, which were of great relevance for society and surpassed sports and mere entertainment in importance. Concurrently, the newspaper seemed to adopt two strategies for overcoming its financial crisis and for expanding its number of readers.

On the one hand, it continued to incite the fans' passion for their teams, making the Monday issue reach almost 65,000 copies (MORAES, 1997, p. 85) in the day after a match with the city's most important teams, in a time when the Maracanã stadium recorded its highest average attendance. On the other hand, following closely visual reforms adopted by many magazines in the decades subsequent to World War II, the newspaper brought new journalistic writing standards, hiring high trained professionals and publishing inserts that would call the attention of artists from all over the country.

In addition to a small encyclopedia entitled Anuário de Cultura [Culture Yearbook], the newspaper's most important supplements were JS Culture, JS Youth, JS Cartoon, JS $\mathrm{School}$, and, later, $\mathrm{O} \mathrm{Sol}$, an alternative project, a kind of cultural section that served as a free experiment for apprentices, trainees and neophytes at journalism, graduates of the first journalism universities, whose mandatory certificate for exerting the profession would be 
instituted by the authoritarian legislation of 1968 .

The new editor took a risk by publishing a sports newspaper at the same time cultural and educational, with emphasis on the dynamism of the youth sector and their thematic broadly ranged preferences. It also comprised a choice and an initiative in the midst of changes in the sector that started in the previous decade and that became more urgent at the time.

In the late 1960s and the early 1970s, the newspaper editors shared the principle that "the entire nation must develop the sport, benefiting from youth's strength and enthusiasm" (JORNAL DOS SPORTS. 13 de março de 1971, p. 04).

Thus, they sensed youth's quantitative and qualitative potential that seemed to conquer quickly a place in the world and in Brazilian society. The identity of young people as an independent social group had already been recognized and the formation of a specific youth subculture was increasingly prominent.

The "youth culture" so divulged by the media obtained visibility and international magnitude in devising a series of values and standards of sociability. Differentiating itself from other segments, it pursued its contrastive elements with great emphasis in the areas of language, behavior, and music. Youth also assumed a leading position in questioning family structure and in behavioral controversies over sexual freedom and use of contraceptives. These claims forged a specific ethos and lifestyle, which opposed greatly to their parents' generation.

The juvenile enthusiasm would surpass schools and universities boundaries not only in the form of protests, rallies and public demonstrations. Soon it would be appropriated and broadcast by mass media language. In the beginning a form of expression alternative to capitalist way of life, yet to flourish, "youth culture" would also be subjected to rapid assimilation by the consumer society and cultural industry, with their ability to absorb and produce identities and lifestyles exportable to different latitudes of the world.

Jornal dos Sports' re-structuration was not contrary to this social unrest and this communicative dynamics, both in national and international scale. Mindful and sensitive to those circumstances, Mário Júlio Rodrigues sought to be attuned to a time that converged to youth's assertion as a cultural hegemonic force. When O Sol (the Youth Power's Newspaper) was published, this sports daily newspaper would put itself in the position of spokesperson and conscience of a singular and historical world phenomenon:

Young people make a newspaper for young people. All the strength, all the inventive power, all the fighting spirit of youth are in the pages of Sol. It is a new way of seeing the world. It is a fresh newspaper concept. For hundreds of years it is said that the sun rises for everyone. Now this is really certain. Sol rises for everyone. And you will see that in fact everything is 
new under Sol (Ibid. 18 de setembro de 1967. Advertisement of SOL).

The cultural power. The social power. The political power. Since the end of the last war the world watched, powerless, the youth's rebellion. The elements unleashed by the war, 20 million young people sacrificed in the carnage were enough for young people to aspire, from that moment on, to hegemony in the process of social development. (...) The 1960s shall be remembered as the decade of youth revolution (Ibid. 26 de novembro de 1967, p. 5).

It can be said that Jornal dos Sports engaged in university students' politicisation. In July 1968, the announcement of José Arthur Poerner's book (1978), a work dealing with the history of student activism in Brazil, occupied an entire page of the newspaper and was in consonance with the warm atmosphere of the marches in Rio de Janeiro, then in their climax. Poerner devoted his study to a historical chronology of the struggles of the Students' National Union, UNE, which then completed thirty years of existence.

\section{Young Supporters leading role in Jornal dos Sports coverage}

Unnoticed aspect to many scholars of press and contemporary history, in a dictatorial period that has been well explored regarding politics, economy and culture, eclipsed perhaps for more important events, the youth ideas disseminated in various dimensions of everyday life also influenced sports and, most of all, a significant sphere of leisure in national everyday life: football.

It is possible that it happened because sports newspapers have historically enjoyed low prestige, commonly regarded as minor or second class news. Such rehabilitation follows the methodological suggestion made by the American historian Robert Darnton: to focus on publications and books forbidden or underestimated writers and mediocre illuminist writers from the French Ancien Régime (DARNTON, 1987).

So, under his influence, we start from the apparently uninspiring and "forgotten" fact that the year of 1968 saw the emergence in Rio de Janeiro of new football fans groups that adopted the denomination of Young Supporters Groups, simultaneously with the penetrating circulation of the youth power slogan, whether in the referred newspaper, or in society in general.

Jovem Flu was created then by a group of artists and Fluminense fans, which is said to have at that time about 200 supporters, such as Chico Buarque and Hugo Carvana. The latter would appear in the newspaper's front page photo next to Nara Leão and Wilson Simonal, with his guessesfor the Fla-Flu [Flamengo x Fluminense] match (Jornal dos Sports. 11 de agosto de 1968, p. 01). 
Another group was called Flamengo's PoderJovem, made of dissident members of the club and of the traditional Jaime de Carvalho's group. Besides, there was Botafogo's PoderJovem, made of a group of friends and Copacabana residents, who used to watch the games together in the stadium. As for Vasco da Gama matches, Jornal dos Sports used to make reference to a phrase from an anonymous banner: "The Psychodelic Supporters Group from Niterói is always there with Vasco", what made clear the free international circulation of slogans from youth movements, such as counterculture.

It is possible to point out how, during the second half of the $20^{\text {th }}$ century, the attendance, the behavior and the profile of match goers were changing continuously, following transformations that occurred in the society. In Rio de Janeiro, the emergence of supporters' groups that called themselves young seems appropriate for this transformation.

The dramatization at both national and international levels of a "generational crisis" became manifest not only in the family, the school or the university. A minor phenomenon, at first without greater relevance, which passed unnoticed for many researchers, the Young Supporters Groups from Rio de Janeiro emerged as an original fact, as a new center of youth grouping, created by new actors aiming a distinguished role in the sports scene.

In general, they appeared concurrently with major events triggered by young people in Brazil and in the world; in particular, their anti-establishment position questioned the Supporters' Groups that since the 1940s, 1950s and 1960s already had their places in the stands and already had recognition in Rio de Janeiro's sports scene.

These traditional groups, created by the clubs to motivate the teams and excite the audience in match days, were supported by competitions promoted by Jornal dos Sports, since the time of Mário Filho. In an unified and similar way, they were settled in the stands as official representatives of the fans, each one led by a single leader. During the decades the leaders became the middleman between fans and other football protagonists, such as club directors, reporters and players.

Besides demanding a more homogeneous age profile, the Young Supporters distinguished themselves from the former groups by incorporating a controversial value: the protest. If until that time motivating seemed to be the essence of fans activity and the final purpose of these associations, the Young Supporters Groups channelled dispersed dissatisfaction among fans during their team's period of crisis, granting themselves free right to pressure, jeer and boo the club's board, which was favored by the absence of direct personal links with club directors.

The principle of unrestricted support to the team was questioned, as well as the historical link between the club and the fans. The dissent was expressed in two ways: on the 
one hand, by the non-recognition of official supporters' leaders exclusive authority; on the other hand, by the ability to interfere as an external force, independent from the club and making pressure from the outside, from the stands to the field. In this sense, the media was also a privileged place for demonstrating dissatisfaction and to exert a new type of participatory influence of Young Supporters over the clubs, which seemed to have the support of Jornal dos Sports and its editorial line that favored and boasted among its readers the importance of Youth Power in Brazil and in the world, in society and in sports.

In the turbulent historical context of the late 1960s, particularly in 1968, during general Costa e Silva's rule, the Jornal dos Sports gave considerable emphasis on massive student demonstrations, describing confrontations between students and the police and monitoring the negotiations between student leaderships and representatives of the Ministry of Education, among them the audience with Minister Tarso Dutra, collective acts at Gustavo Capanema Palace which gathered up to 50,000 demonstrators in the city center (Ibid. 05 de julho de 1968, p. 12).

Jornal dos Sports' explicit support to students seemed to spread to football, more intensively in backing up contestations of the newly formed groups of fans, with editorials entitled "The power of the crowd" (Ibid. 12 de dezembro de 1967, p. 03), with specific columns called "The Supporters' game” (Ibid. 29 de abril de 1968), with photos followed by captions such as "They play too" (Ibid. 01 de abril de 1967, p. 10) and conclusive sayings in the front page: “... an indisputable force in Brazilian football” Ibid. 05 de abril de 1971, p. $01)$.

\section{Protests from the stands (I): the Jovem Flu movement in 1968}

The independence claimed by Rio de Janeiro Young Supporters Groups from their respective clubs administration was, at times, more than reported, urged by the newspaper. This occurred, for example, in the first semester of 1968, when the newspaper provided extensive coverage of Jovem Flu opposition movement to Fluminense's board of directors. The movement not yet constituted a Supporters Group formed in the stands, but started from the mobilization of renowned supporters who watched the games in club level seats and incited other supporters with their statements to the media.

In the first semester of that year, Jovem Flu elected as its adversary and persona non grata Fluminense's vice president, Dílson Guedes, responsible, according to the fans, for the team's poor performance in the regional championship. In the campaign for 
deposing him pressure took various forms to express discontentment and it was closely covered in articles such as "Supporters tease Dílson" (Ibid. 01 de abril de 1968, p. 02).

The most significant act was the chant heard in the stands saying "Down with Dílson Guedes!", similar to what students chanted at rallies in that same period: "Down with dictatorship!". Jovem Flu used even more elaborate strategies, such as anonymous calls to the club's vice president and also picketing at his house, with proper press coverage.

In April, Jovem Flu leader appeared in a full-page article to explain the reasons why fans opposed the club's vice president. However, the newspaper's attentions were still divided between Fluminense's supporters agitation and repercussions of the murder of the student Edson Luís in the Calabouço restaurant.

Murdered by the police because he was trying to prevent another rally, this student would become a martyr in the fight against the military dictatorship. Mothers and religious people attended his moving requiem mass in the Candelaria church, which did not prevent great disturbances and clashes between protesters and the police outside the church in downtown Rio. The fierce atmosphere was in the newspaper front page: "Tanks occupy the city" (Ibid.02 de abril de 1968, p. 01), the first Army was called up by the Governor and the director of DOPS made it an excuse for closing the restaurant.

On the other hand, the fatal event would raise society's sensibilities to student issues, swaying public opinion - the Jornal dos Sports published on its front page "Rio mourns students slaughter: police vandalism kills four and injures hundreds" (Ibid. 22 de junho de 1968, p. 01), boasted on the last page a sentence with emotional appeal "it could have been your son" (Ibid. 30 de março de 1968) and published in its school section "Church condemns violence" Ibid.06 de abril de 1968, p. 10 - and receiving the already expected support from intellectuals and teachers. From then on, the newspaper reports are frequent and in the JS School section, they follow step by step the unfolding dispute, with articles spreading police raid at University of Brasilia (UnB) (Ibid.01 de setembro de 1968, Seção JS Escolar, p. 01 and always publishing resounding headlines: "Demonstration and strike against the arrest of Vladimir” (Ibid. 04 de agosto de 1968, Seção JS Escolar, p. 01).

Front page stories covering sports were more scarce, but an article entitled "The supporters' voice" gave word to Hugo Carvana, who accused publicly the retrograde way of thinking of, quoting him, "ultraconservative" Dílson Guedes on managing the club and demanded his immediate resignation. The Club president, Luiz Murgel, defends his ally and accuse the new group of using football as a platform for self-promotion.

The newspaper covered daily the controversy adding a touch of emotion to it and the coverage is still favourable to the supporters, with a relentless campaign for the vice 
president's deposition. Two days later, on April 11, the Jornal dos Sports published a large type front page headline describing the supporters' seeming success: "Dílson Guedes deposed". After three more days, during a match at Maracanã, the newspaper would cover more protests as supporters held symbolic funeral service for the club's president.

\section{Protests from the stands (II): Flamengo's Poder Jovem in 1968}

Flamengo's crisis in the second half of 1968 would also trigger a rough confrontation between the club's presidency and young supporters protests coming from Maracanã's stands. It is necessary to highlight the way that in this case also the Jornal dos Sports would be held as one of the responsible for starting this confrontation. For a whole week in September, the journalist Marcus Aurélio Guimarães wrote seven full-page exclusive and special articles, very appealing, entitled "Flamengo's Undertakers".

In those articles, the journalist focused on corruption-related issues, administrative incompetence and structural problems from the questionable management. A few days later, as the team endured a succession of poor performances, the Jornal dos Sports again reported with sensationalism the team's weaknesses and the fans impatience with the directors. This time, the newspaper covered the Young Supporters' Group protests against President Veiga Brito, former Guanabara congressional representative, member of UDN (National Democratic Union), during his reelection attempt.

Photos and headlines in the newspaper gave an even more dramatic touch to the protests. After a draw with Bangu at Maracanã, the revolt of Flamengo's fans made the columnist Luiz Bayer classify it as "never seen before" (Ibid. 29 de setembro de 1968, p. 04) in the history of the club. Transcriptions of the newspaper's headlines enables an understanding of the articles contents: "Fans are against all" (Ibid.02 de outubro de 1968, p. 04); "Rebellion among supporters", "Supporters repudiate Veiga", "Biggest crisis in the history of Flamengo" (Ibid.21 de fevereiro de 1969, p. 10). Letters supporting Marco Aurélio's article were published: "We demand the heads", "We ain’t no fools".

The newspaper transcribed words of command chanted in the stadium, the first one parodying a sports radio vignette, juxtaposing terms employed by the newspaper ("undertakers") to designate the directors of football: "Oohh, la la / down with the undertakers / where's our money?”; “Organized supporters / Overthrow the plotters!”. The newspaper described the second slogan as "a cry of war, rooted in student demonstrations", a variation of two chants that at the time left-wing activists and underground organizations used to sing: "People organized / overthrow the dictatorship!"; “Armed people / overthrow 
the dictatorship!” (REIS FILHO; FERREIRA DE SÁ, 1985).

Emulated by the newspaper, the fans sought many ways to express their dissatisfaction with the team's critical situation and the club's obscure administration. In addition to chants, the newspaper report showed spontaneous forms of supporters' dissatisfaction demonstrations regarding the club's presidency. These demonstrations could be violent and incisive, e.g. stoning cars in the stadium garage and blocking the president's way out, threatening his physical integrity, or else peaceful and ritualized demonstrations, holding symbolic funeral services for the club's president using coffins in the same way as students did in their rallies.

Exposition of a kind of "representative crisis" within Flamengo fans was quite clear in $J S$ match reports:

Flamengo's supporters who usually place themselves behind the goal rebelled against the
team's poor performance and, in the middle of the second half, formalized their protest:
headed, spontaneously, to the Supporters Group spot, led by Jaime de Carvalho - left side of
the gallery - and started to boo the team more intensely. Jaime launched his protest
immediately, asking for young supporters demonstrations to take place in another location
and even the police was called to remove from there those who insisted on lowering their
flags on the railing, half-mast, a symbol of mourning. Peacefully, the fans followed the police
orders: they walked through the stands, displaying their flags and went to the front of the
radio booths: over there, with no one bothering, away from the officials supporters club, they
kept booing and lowered the flags on the railing. (Jornal dos Sports. 29 de setembro de 1968 ,
p. 16).

The protests led by young supporters and their incipient groups opposed to the club's president Veiga Brito and to the vice president of football Gunnar Goransson, of Swedish origin, would not be restricted to match days and the internal geography of stadiums.

The opposition to the club policies gained the streets, as improvised rallies inspired by student demonstrations carried out at that time in the city center. A funeral procession, a symbolic vigil for President Veiga Brito's death, had a route so unusual as revealing: starting from Maracanã stadium, after another loss, the walk passed by each of the city's most representative newspapers and most well known television networks.

At the end, it arrived at the door of the Jornal dos Sports, on Tenente Possolo Street, where traditionally football fans and students met and where university entrance examination results were published. Amid a chant in unison - "Jornal dos Sports / prominent newspaper / Jorge Veiga Brito /another nail in your coffin!" - the vanguard leaders were invited to the building to explain to the editors the motives of the protests. The reporter Marco Aurélio Guimarães, responsible for the set of articles that stirred the young people to that spontaneous uprising against the leadership of the club, registered:

People who make up Flamengo's Young Supporters Group, those who disagree with everything that is done at the club by Mr. Veiga Brito and Mr. Gunnar Goransson, went to JS to greet the reporter Marco Aurélio for his 'brilliant series of stories he wrote on Flamengo's Undertakers'. José Barbosa Viana, Reginaldo Mota and Gilberto Resende Correia, the elders and leaders of a very large group, made a point of clarifying that, although 
club members 'will no longer attend while Flamengois not giving them the same glory of times past'. And beyond: 'we want Flamengo's greatness and we do not care about who are the men who manage it. The way things are, it is hard to believe that Gunnar and Veiga Brito can raise the morale of the team. We will still suffer a lot more, but our day is coming. This board is horrible and we could only assess the mistakes made after series of stories Flamengo's Undertakers (Ibid. 02 de outubro de 1968, p. 02).

The description of the facts above registered by a newspaper in the turbulent second half of the year of 1968 is necessary, insofar as it gives brighter colors and provides the perception of introduction of new elements to the experience of professional football in Rio de Janeiro. Though ephemeral, influenced by historical circumstances of youth protests, these events stimulated the emergence of a new type of fan, who express themselves collectively and are not satisfied with a situation of passivity or with the traditional characterization of the " $12^{\text {th }}$ player".

\section{In conclusion: a balance of protests from fans in the late 1960s}

The episodes described above illustrate a formation process of a profile of club engagement that emerged in the stands and would live through the following decades. They show how a kind of sports' vanguard was articulated in a space dedicated to assistance, headed by young people who felt capable of assuming also an active role (or reactive) and an engaging, even if circumstantial or episodic, in football.

The importance of giving these groups of a youth vanguard character is due to the proximity atmosphere evoked by its methods of action and mobilization compared to other civil society movements. The protesting walks, the claiming for rights and suspicion before the instituted authorities seemed to be mirroring points among young fans and students, although it is not possible to assess to what extent there was a concrete intercession between the two.

Even if it was not possible to establish a direct link between the protagonists and that they were parallel phenomena, whose comparison could be only at the level of analogy, the similarity of expression made possible to suggest of tuning and sharing of a same ambience of revolt.

It is possible to assure that football and the student protests of that period were the two largest mass events of the city of Rio de Janeiro. The newspaper reported the mayhem to purchase advance tickets for the games at the box office of the Municipal Theatre, in Cinelândia, arising from queues that reached kilometers going all the way to city center during the week, as showed the panoramic pictures of the newspaper. The Maracanã stadium accommodated in the decisive matches over 150,000 fans, while the students marches 
crowded into the center of Rio up to (as it was legendarily known) 100,000 people.

The examples listed are enough to show the background of upheaval and transformation of a series of values then dominant in the late 1960s. In this sense, the intention was to demonstrate the junction between the emergence of Rio's Young Supporters Groups and other historical events that took place in the country and in the city of Rio de Janeiro, to clarify the extrapolation of the meanings of this juvenile phenomenon occurred in the stands of Maracanã, commonly restricted to the sports' world.

If it is true that this had a unique internal logic that linked to a process of transformation of professional football and an obvious challenge of traditional collective forms of hope coming from the 1940s, 1950s and 1960s, the perception that the advent of Young Supporters Groups falls outside football borders and fits in a greater social, political, cultural and artistic dimension is also possible.

The contrast to symbols of power established in the world of football in 1968 also marked the appearance of others, related in an international scale to the repercussions of invention of a way of being young in the West, known equally as counterculture. Added to this, the young fans were also stimulated by the example of various mass civil movements and contesting public events that happened over and over at Rio de Janeiro at the time.

Locally, the opposition of those young supporters groups to the board of their clubs was also articulated to a clear incentive on the part of major mass media, such as the Jornal dos Sports, whose commercial propaganda strategy and editorial policy were aiming at the support of public initiatives.

The contextualization of the phenomenon of Rio's Young Supporters Groups allows an understanding of some of the factors that led to their appearance in 1968, such as reported and dramatized by the press selected here. At the same time, it shows that some nuances of its historical peculiarity related to a capital stage of national politics, and the city of Rio de Janeiro in particular, in which the means of expression and manifestation, although suppressed, found room to reverberate in the Brazilian society.

While in Rio de Janeiro the first Young Supporters Groups, such as Flamengo, Fluminense and Botafogo, arose on 1967-68, under a boiling political atmosphere and growing challenge to the usual forms of authority; in São Paulo, the new supporters' groups would be founded only after 1969, when the Institutional Act No. 5 was already deployed and the political participation and freedom of expression of the media had been restricted in its almost totality.

Although the foundation of the Gaviões da Fiel of Corinthians and Santos' Supporter Group in 1969, the Torcida Uniformizada do Palmeiras (TUP) in 1970, and the Torcida 
Independente do São Paulo in 1972 dramatized questions very similar to their Rio's counterparts - opposition and autonomy faced with the authoritarian direction of clubs and insubordination to the traditional leaders of supporters' groups - the dictatorship phase following the implementation of the dictatorial AI-5 put other parameter to football organized groups, beyond the universe of sport.

Not without reason, in the 1970s they began to be associated with other forms of expression and historical experiences, with the gradual and progressive exclusion of its horizon of student marches and youth engagement. Going to the incorporation of other identity elements inside of what is understood as a young ethos. It is on this new cultural, sports and social reality - and still in the light of these representations as filtered by a particular sporting press - that organized supporters' groups will be developed, as well as the Young Supporters Groups here alluded, in particular, in the late 1970s.

\section{Bibliographic references}

DARNTON, Robert. Boemia literária e revolução: o submundo das letras no Antigo Regime. São Paulo: Companhia das Letras, 1987.

GINZBURG, Carlos. Mitos, emblemas e sinais: morfologia e história. São Paulo: Companhia das Letras, 1990.

LOPES, José Sérgio Leite."A vitória do futebol que incorporou a pelada". In: Revista USP. São Paulo: s.e., 1994, n 22, p. 78 e 79.

MORAES, Dênis. de. O rebelde do traço: a vida de Henfil. Rio de Janeiro: José Olympio, 1997.

NORA, Pierre; LE GOFF, Jacques. (Orgs.). História: novos problemas, novas abordagens, novos objetos. Rio de Janeiro: Editora Francisco Alves, 1988, 3 vols.

POERNER, Arthur José. Poder Jovem. Prefácio de Antônio Houaiss. Rio de Janeiro: Civilização Brasileira, 1978.

REIS FILHO, D. A.; FERREIRA DE SÁ, J. Imagens da revolução. Rio de Janeiro: Marco Zero, 1985. 


\section{Primary Source Consulted}

ARQUIVO HISTÓRICO DO JORNAL DOS SPORTS. Rio de Janeiro. 1967-1968.

Recebido: 04/05/2019

Aceito: $30 / 06 / 2019$

Publicado: 04/09/2019

\footnotetext{
${ }^{\mathrm{i}}$ É professor-adjunto da Escola de Ciências Sociais, da Fundação Getúlio Vargas (FGV/CPDOC). É pósdoutor pela Maison des sciences de l'homme de Paris e pela University of Birmingham. E-mail: bernardobuarque@gmail.com
} 